\title{
Scrotal Basal Cell Carcinoma-A Rare Manifestation
}

\author{
Tugba Kevser Uzuncakmak ${ }^{1}$, Defne Özkoca ${ }^{1}$, Bengu Cobanoglu Simsek ${ }^{2}$, Server Serdaroğlu ${ }^{1}$
}

1 Istanbul University, Cerrahpasa, Cerrahpasa Medical Faculty Department of Dermatology, Istanbul, Turkey

2 Istanbul Medeniyet University Medical Faculty, Department of Pathology, Istanbul, Turkey

Citation: Uzuncakmak TK, Özkoca D, Simsek BC, Serdanoğlu S. Scrotal basal cell carcinoma - a rare manifestation. Dermatol Pract
Concept. 2022;12(1):e2022004. DOI: https://doi.org/10.5826/dpc.1201a04

Accepted: April 13, 2021; Published: January 2022

Copyright: $\bigcirc 2022$ Uzuncakmak et al. This is an open-access article distributed under the terms of the Creative Commons AttributionNonCommercial License (BY-NC-4.0), https://creativecommons.org/licenses/by-nc/4.0/, which permits unrestricted noncommercial use, distribution, and reproduction in any medium, provided the original authors and source are credited.

Funding: None.

Competing interests: None.

Authorship: All authors have contributed significantly to this publication

Corresponding author: Tugba Kevser Uzuncakmak, MD, Istanbul University Cerrahpasa Medical Faculty, Department of Dermatology, Istanbul, Turkey. E-mail: drtugbakevser@gmail.com

\section{Case Presentation}

A 68-year-old male presented with a 6-year history of a slowly growing ulcerated lesion on the scrotum. Dermatological examination revealed a polypoid lesion of $2 \times 2 \mathrm{~cm}$ on an erythematous base on the left scrotum. The surface was ulcerated, and microbleeding spots were observed (Figure 1, A and B). No other lesions were present. Contact dermoscopy of the lesion revealed polymorphic linearly grouped dotted vessels and short linear vessels. Surface ulceration was prominent with the rope sign. Crystallite structures were evident in the left lower quadrant. (Figure 1C). The patient was referred for total excision. The histopathology revealed basal cell cancer of metatypical type (Figure 1D). No new lesions were observed in the biannual follow-up visit.

\section{Teaching Point}

Basal cell carcinoma is the most common type of cancer that is commonly seen on sun-exposed areas, yet it is rarely seen on the genitalia. Despite its rarity, genital basal cell carcinomas have increased risk of distant metastasis. Therefore, after the initial therapy, long-term follow-up is mandatory in these cases. 


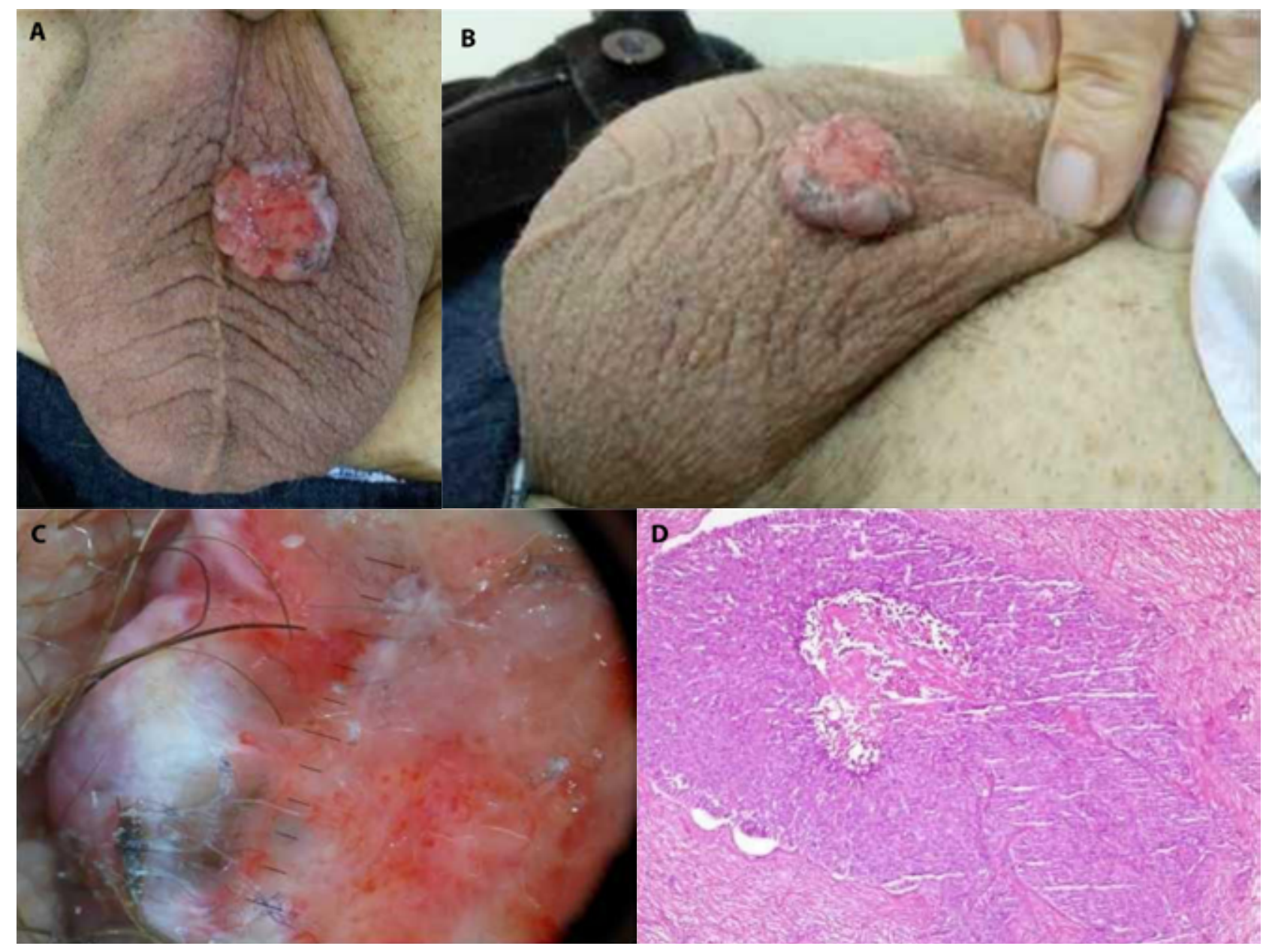

Figure 1. (A and B) A $2 \times 2 \mathrm{~cm}$ sized, polypoid, centrally ulcerated tumoral lesion on an erythematous base on the left scrotum. (C) Polymorphic linearly grouped dotted vessels and short linear vessels. Surface ulceration was prominent with the rope sign. (D) Widespread ulceration on the surface. Tumor cells proliferating as nodular structures from the basal layer to the stroma had pale large cytoplasm $(\mathrm{H} \& \mathrm{E}, \times 100)$.

\section{References}

1. Han S, Zhang Y, Tian R, Guo K. Basal cell carcinoma arising from the scrotum: an understated entity. Urol Case Rep. 2020;33:101332. DOI: 10.1016/j.eucr.2020.101332. PMID: 33102034 ; PMCID: PMC7573964.
2. Dai B, Kong YY, Ye DW, Xu XW, Yao XD, Zhang SL. Basal cell carcinoma of the scrotum: clinicopathologic analysis of 10 cases. Dermatol Surg. 2012;38(5):783-790. DOI: 10.1111/j.15244725.2012.02356.x. PMID: 22309181. 